\title{
Edge effects and human disturbance influence soil physical and chemical properties in Sacred Church Forests in Ethiopia
}

\author{
Catherine L. Cardelús $(\mathbb{D}$ - Amare Bitew Mekonnen - Kelsey H. Jensen • \\ Carrie L. Woods • Mabel C. Baez • Martha Montufar • Kathryn Bazany • \\ Berhanu Abraha Tsegay • Peter R. Scull • William H. Peck
}

Received: 24 September 2019 / Accepted: 5 June 2020 /Published online: 23 June 2020

(C) The Author(s) 2020

\begin{abstract}
Aims Tropical forests are increasingly threatened by edge effects as forest degradation and deforestation continues, compromising soil integrity, seedling regeneration capacity, and ecosystem services. Ninety-three percent of the last remaining forests of northern Ethiopia, which number 1022 in the South Gondar region of our study, are $<16$ ha and are protected because they have a Tewahido Orthodox Christian church at their center. The aim of this study was to determine the effects of human disturbance, forest size, distance from
\end{abstract}

Responsible Editor: Zucong Cai.

Electronic supplementary material The online version of this article (https://doi.org/10.1007/s11104-020-04595-0) contains supplementary material, which is available to authorized users.

C. L. Cardelús $(\bowtie) \cdot$ M. Montufar $\cdot K$. Bazany

Department of Biology, Colgate University, Hamilton, NY, USA

e-mail: ccardelus@colgate.edu

A. B. Mekonnen · B. A. Tsegay

Department of Plant Biology, Bahir Dar University, Bahir Dar, Ethiopia

K. H. Jensen

Department of Ecology and Evolutionary Biology, Cornell

University, Ithaca, NY, USA

C. L. Woods

Department of Biology, University of Puget Sound, Tacoma, WA, USA

e-mail: cwoods@pugetsound.edu population center and other factors on the soil properties and nutrient status of sacred church forests. We also compared forest soil physical and chemical properties across land cover types in these forests.

Methods We assessed the soil physical (water content and bulk density) and chemical (total carbon and nitrogen, available phosphorus, ammonium) properties of 40 sacred church forests across three spatial scales: within individual forests; among forests; and across land cover type (forest, forest edge-exterior, Eucalyptus plantation). We used

\section{C. Baez}

School of Forest Resources and Conservation, University of Florida, Gainesville, FL, USA

P. R. Scull

Department of Geography, Colgate University, Hamilton, NY, USA

W. H. Peck

Department of Geology, Colgate University, Hamilton, NY, USA 
distance from the edge within each forest to examine edge effects on soil nutrients.

Results We found that nutrients and carbon decreased significantly from the interior to the outer edge of these forests and with forest size. Further, the soil of Eucalyptus plantations and areas outside of the forest were largely indistinguishable; both had significantly lower nutrient concentrations than sacred church forest soil. Conclusion Our research highlights the insidious impacts of edge effects and human disturbance on forest soils and the need for an integrated soil management program in the region that balances local needs with forest conservation. The conservation of these sacred church forests is important for maintaining regional soil nutrient status relative to agricultural lands and Eucalyptus plantations.

Keywords Land-use change $\cdot$ Sacred forest $\cdot$ Sacred grove $\cdot$ Church forest $\cdot$ Eucalyptus plantation $\cdot$ Tropical forest soil · Forest conservation · Shadow conservation . Edge effects · Soil nutrients · Fragmentation ·

Disturbance

\section{Introduction}

Land-use and cover change (LUC) leads to biodiversity loss and weakens ecosystem function (Villalobos and Vamosi 2016; Cardelús et al. 2017). In tropical ecosystems, LUC frequently results in fragmentation of large forests into smaller, discrete patches. This is one of the strongest drivers of declining forest health as it introduces stressors affecting animal habitat, plant community structure, and soil status (Laurance et al. 1997, 2011, 2012; Echeverria et al. 2006; Wassie et al. 2010). Recent research has found that $70 \%$ of tropical forests are within $1 \mathrm{~km}$ from a forest edge and 20\% within $100 \mathrm{~m}$ (Haddad et al. 2015). Deforestation produces an abrupt boundary between the forest and surrounding matrix which result in edge effects. Studies in the Brazilian Amazon have shown that edge effects result in greater light intensity, lower moisture, and higher wind disturbance which can be felt up to $300 \mathrm{~m}$ into the forest (Laurance et al. 2011). These effects can lead to degradation of soil health and also affect fundamental ecosystem processes such as litter decomposition rates (Riutta et al. 2012), and forest productivity (Laurance et al. 2018).

Forest soils support plant and animal life while providing ecosystem services such as nutrient cycling and storage, and water filtration and water holding capacity (Delgado and Gantzer 2015). Edge effects have been shown to impact soil health by decreasing total carbon (C) and nutrients [nitrogen $(\mathrm{N})$, phosphorus $(\mathrm{P})$ ], shifting stoichiometric nutrient balances $(\mathrm{N}: \mathrm{P}$ ratio, $\mathrm{C}: \mathrm{N}$ ratio), decreasing available nutrients (orthophosphate, ammonium), increasing bulk density $\left(\mathrm{g} \cdot \mathrm{cm}^{-3}\right)$ and decreasing gravimetric water content (GWC) (Guo and Gifford 2002; Huth et al. 2012). Increasing bulk density limits water penetration, soil pore space, aeration and microbial activity, all of which decrease nutrient availability for plant growth. The negative impacts of edge effects on soil quality are paralleled by declines in aboveground net primary productivity (ANPP), biodiversity, and overall forest health (Laurance et al. 2018). Quantifying the impact of forest fragmentation and degradation on forest soils is a critical first step to understanding their effects on ecosystem services and biodiversity.

Ethiopia is undergoing higher rates of deforestation than many other parts of Africa, losing 141,000 ha of forest in 2010 alone (Laurance et al. 2018). The northern highlands of Ethiopia are an extreme example of forest fragmentation, where forest patches are distributed in a matrix of agricultural and grazing land (McCann 1997; Aerts et al. 2016). Deforestation and loss of biodiversity are more common and severe in the northern and central highlands of Ethiopia than in the south due to intensive economic pressure on forest lands for human use and for cash crop production, such as is seen with the introduction of Eucalyptus plantations (Klepeis et al. 2016; Liang et al. 2016). The fragmentation of these forests is at least 50 years old as determined by comparison with satellite imagery from the 1960's (Cardelús et al. 2017). What remains in the region are small, isolated forest fragments exclusively found surrounding churches of the Ethiopian Orthodox Tewahido Church, known as sacred church forests (Wassie 2002; Boerma 2006; Cardelús et al. 2013). Such forest fragments persist because they surround the church, a form of accidental or shadow conservation (Dudley et al. 2009; Cardelús et al. 2017).

The South Gondar zone in Northern Ethiopia has 1022 church forests across 9 Woredas or political states. These sacred forests vary in elevation (1800-3000 m), size (1.4 ha - $147 \mathrm{ha}$; $93 \%$ less than $16 \mathrm{ha}$ ), distance to population center (i.e. $<50 \mathrm{~km}$ or $>50 \mathrm{~km}$ ), the degree of disturbance (13-86\%) (Cardelús et al. 2019) and the presence of a protective wall surrounding the forest (Cardelús et al. 2017; Woods et al. 2017). The degree 
of disturbance was quantified by Cardelús et al. (2019) as the percent of various disturbances across the forests (e.g. weedy taxa, native and exotic tree plantations, clearings/gathering areas, buildings, graves).

These sacred church forests present a unique opportunity to study the effects of extreme tropical forest fragmentation on soil health with respect to both fragment size and degree of disturbance. On average, in forests $<16$ ha, over half of the area show signs of disturbance, negatively impacting tree species richness, abundance, and biomass, as well as seedling richness and abundance (Cardelús et al. 2019). The intensive anthropogenic disturbance of these forests and the total conversion of the area surrounding the forest, the matrix land, for agriculture, livestock farming (e.g. maize, barley, teff, wheat) and Eucalyptus plantations (Nigussie et al. 2017; Scull et al. 2017) have clear negative impacts on aboveground biomass and biodiversity (Cardelús et al. 2019). Less visually obvious are the impacts of fragmentation and disturbance on ecosystem function and services related to soil health. We predict that high disturbance is negatively impacting soil health in these forests, which may feedback into the observed detrimental effects on aboveground biomass.

In this study, we examined the effects of forest size, distance of the forest from population center, elevation, the presence of a wall around the edge of the forest and the degree of disturbance on 40 sacred church forest soils physical (water content and bulk density) and chemical ( $\mathrm{C}$ and $\mathrm{N}$, available $\mathrm{P}$, ammonium) properties across three spatial scales: within individual forests; among forests; and across land cover type (forest, forest edge-exterior, Eucalyptus plantation). We hypothesize that soil health will be more negatively affected by decreasing forest size, decreasing distance to edge, and increasing disturbance, and will be more positively affected by increasing distance from population centers and the presence of a wall. We also hypothesize that the forest edge-exterior and Eucalyptus plantations will have lower soil health compared to forest interiors.

\section{Methods}

Study area

This study was conducted in South Gondar Administrative Zone (SGAZ), Amhara National Regional State, Ethiopia (Fig. 1; 14,607 km², $11^{0} 02^{\prime}-12^{0} 33^{\prime} \mathrm{N}$ and $\left.37^{0} 25^{\prime}-38^{0} 41^{\prime} E\right)$. The elevation ranges from 1202 to $4231 \mathrm{~m}$ above sea level. The annual average rainfall ranges from $700 \mathrm{~mm}-1300 \mathrm{~mm}$, with most falling during the wet season, June - August. Annual average temperatures range from $9.3{ }^{\circ} \mathrm{C}-23.7^{\circ} \mathrm{C}$ (Wassie et al. 2009a). The common soil types in the region are Vertisols, Cambisols, Rigosols, Liptosols, Flovisols and Arenosols (Wassie et al. 2010). The total forest cover in SGAZ is 20,882 ha, comprising 16,660 ha of natural forest and 4222 ha of plantations, which accounts for only $1.4 \%$ of the total area of SGAZ (SGAZDA, 2004).

\section{Study sites}

Approximately one thousand sacred church forests have been identified in the SGAZ, with an average size of $\sim 5$ ha (Cardelús et al. 2017). We selected 40 sacred church forests using aerial images from Google Earth in stratified sampling based on elevation (montane 1800-2050 masl/upper montane, 2400-2700 masl), size of the forest (1.4-15.4 ha), distance from the two main population centers, Debre Tabor and Bahir Dar, and the presence of a wall (Table 1, Fig. 1). This study focuses on small forests because more than $90 \%$ of all church forests in SGAZ are less than 16 ha. Previous research in this system indicates that the presence of a stone wall surrounding a sacred forest is important for reducing disturbance from pastoral grazers and increases seedling recruitment (Wassie et al. 2009b; Cardelús et al. 2017, 2019; Woods et al. 2017); hence, we included the presence of a wall in our study and selected 22 forests that had a wall and 22 without a wall (Table 1).

Soil collection

Soil samples were collected volumetrically in triplicate from each of three, $10 \times 10 \mathrm{~m}^{2}$ long-term study plots established in each church forest $(n=9)$ between 2012 and 2018, $10 \mathrm{~m}$ directly exterior (edge-exterior) of the forest from the non-agricultural matrix $(n=3)$, and when present, from within Eucalyptus plantations adjacent to the forest $(n=3)$ for a total of 12 or 15 soil samples per site (Table 1; Fig. 2). In order for three, $10 \times 10 \mathrm{~m}$ plots, to be established within each forest, we had two different plot arrangements depending on forest size. Forests that were $>60 \mathrm{~m}$ from church interior wall to forest edge had plots arranged in sequence from the center to the edge, while forests $<60 \mathrm{~m}$ from the church 


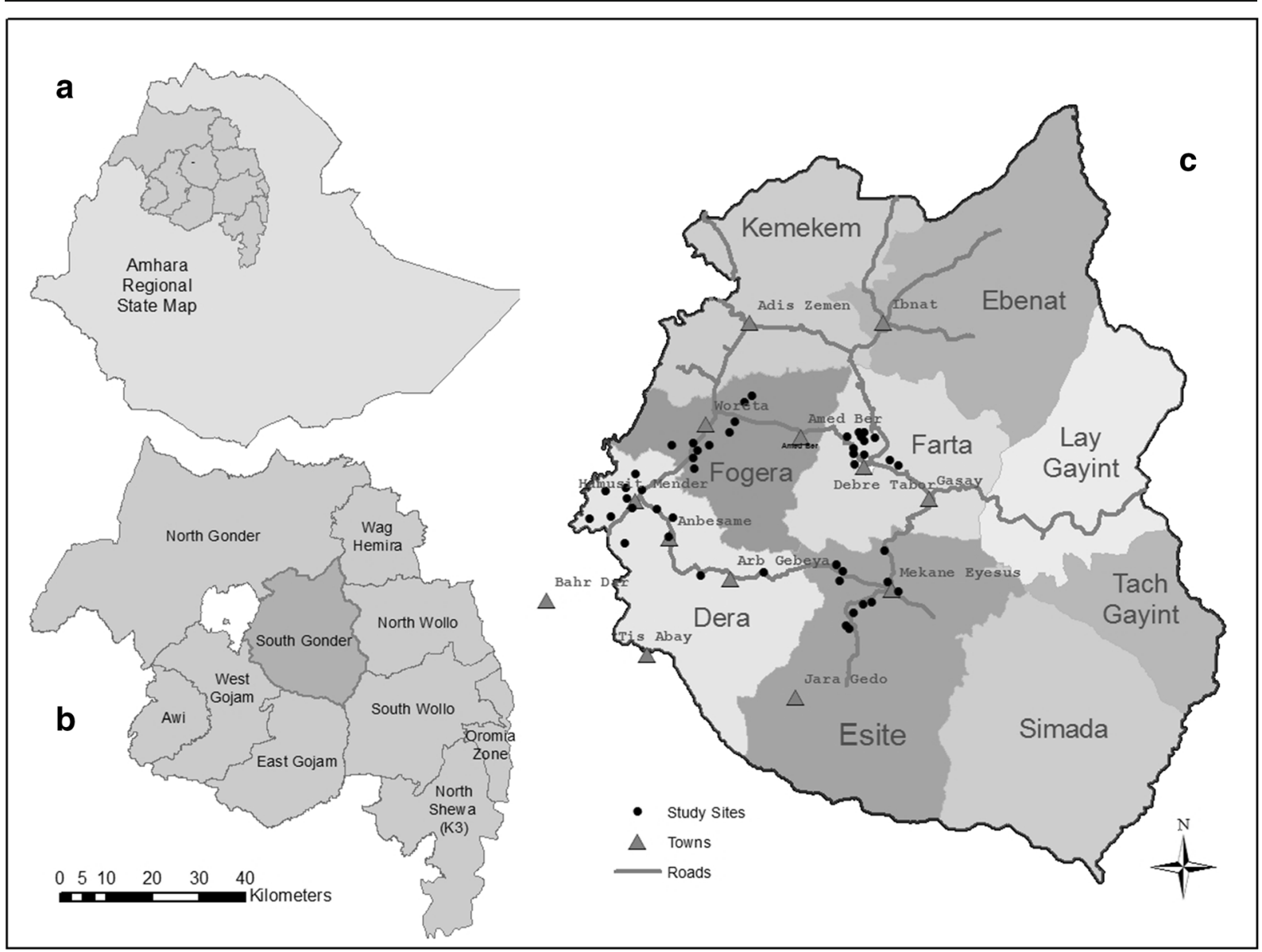

Fig. 1 Map of study region: (a) Ethiopia with the Amhara regional state where this study takes place; (b) the ten Amhara regions, or states; (c) the South Gondar Administrative Zone (SGAZ, study area) and its 9 Woredas (political areas), and the locations of sacred forests studied

Table 1 Number of land cover types from which soil was collected across sample categories. Eucalyptus plantations were not found at all sites

\begin{tabular}{|c|c|c|c|c|}
\hline $\begin{array}{l}\text { Distance from Bahir Dar (montane) } \\
\text { or Debre Tabor (upper montane) }\end{array}$ & Land Cover Type & Wall/No Wall & $\begin{array}{l}\text { Montane } \\
(1800-2050 \mathrm{~m})\end{array}$ & $\begin{array}{l}\text { Upper Montane } \\
(2400-2700 \mathrm{~m})\end{array}$ \\
\hline \multirow[t]{4}{*}{$\operatorname{Near}(<50 \mathrm{~km})$} & \multirow[t]{2}{*}{ Forest } & Wall & 8 & 4 \\
\hline & & No Wall & 4 & 6 \\
\hline & Exterior & & 12 & 10 \\
\hline & Eucalyptus Plantation & & 2 & 6 \\
\hline \multirow[t]{4}{*}{$\operatorname{Far}(<50 \mathrm{~km})$} & \multirow[t]{2}{*}{ Forest } & Wall & 5 & 4 \\
\hline & & No Wall & 4 & 4 \\
\hline & Exterior & & 8 & 8 \\
\hline & Eucalyptus Plantation & & 4 & 3 \\
\hline
\end{tabular}



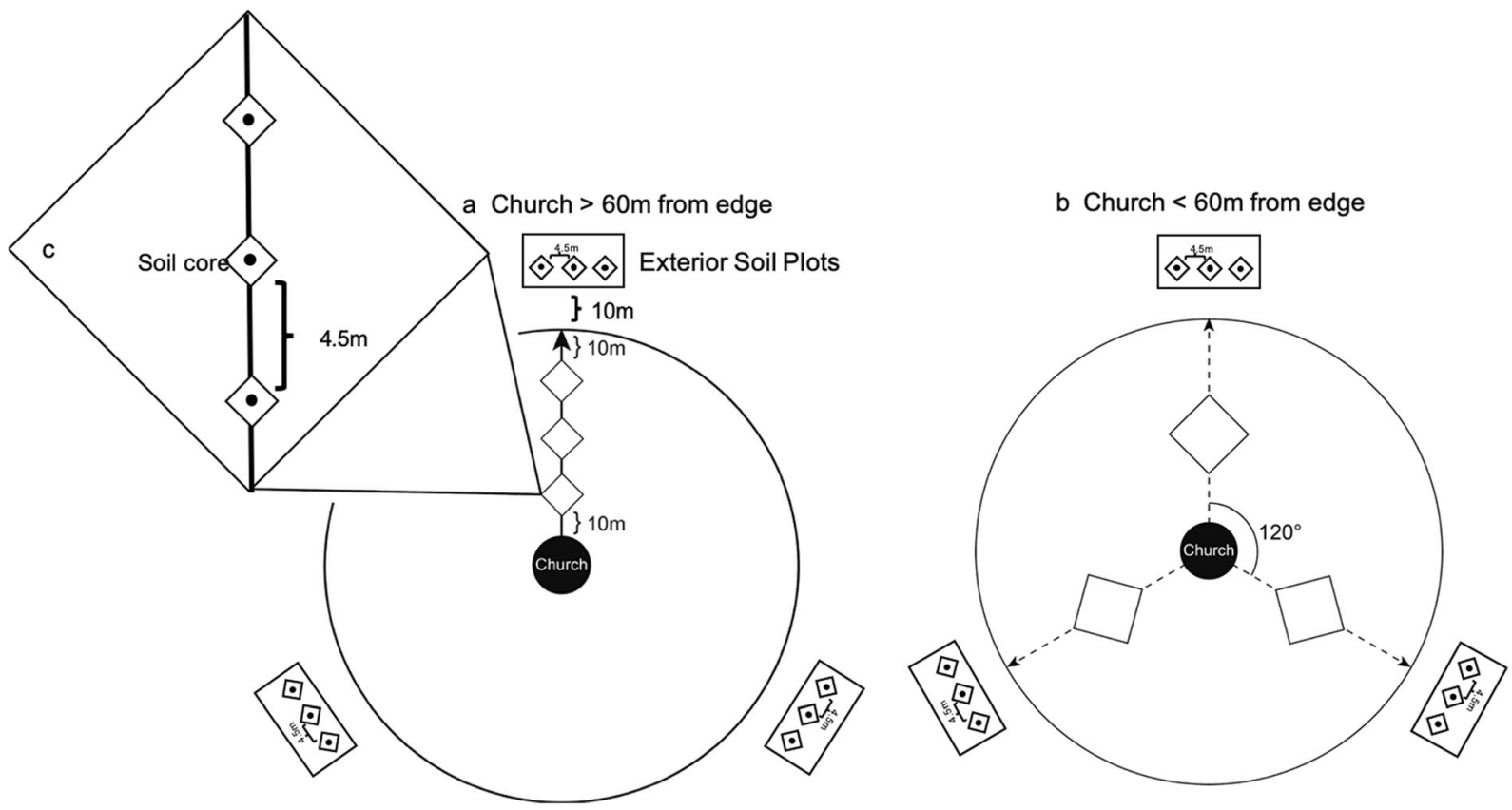

Fig. 2 Plot arrangement in forests with a. $>60 \mathrm{~m}$ between the church wall and forest edge; $\mathbf{b} .<60 \mathrm{~m}$ between church wall and forest edge; and c. arrangement of soil cores within a plot. Edgeexterior soil cores were collected at three compass directions

interior wall to forest edge had plots that were established at 3 cardinal directions around church within $10 \mathrm{~m}$ of the edge (Fig. 2). Three volumetric soil cores were collected $4.5 \mathrm{~m}$ apart within each plot to $10 \mathrm{~cm}$ in depth. All litter was removed down to the O horizon before sampling. Soil samples were collected once for each forest between 2014 and 2017.

Soil properties and nutrient analyses

Across 40 forests ( $n=9$ samples/forest), 15 Eucalyptus plantations (3 samples/plantation) and 38 edge-exterior sites (3 samples/site), we collected 519 soil samples (Table 1). Soil samples were homogenized and passed through a $2 \mathrm{~mm}$ sieve before being processed and analyzed for nutrients. Bulk density $\left(\mathrm{g} \bullet \mathrm{cm}^{-3}\right.$, oven dried mass/sample volume (Blake and Hartge 1986)) was measured for all soils except for sites 4, 6, and 10 because of a laboratory error. Percent $\mathrm{C}$ and $\mathrm{N}$ of oven dried soil samples were determined using elemental analysis (ECS 4010, Costech Analytical Technologies, Inc., Valencia, California). Total P of soil samples ( $\mu \mathrm{g}$ P - $\mathrm{g}_{-}{ }^{1}$ dry soil) was determined by colorimetry after acid ash-digestion (Jones and Case 1996). C:N ratio and N:P ratio were then calculated. around each forests. Eucalyptus plantations, when present adjacent to the forest, were collected in triplicate as per edge-exterior soil plots

All soils collected during the dry season (forest $n=30$ ) were further analyzed for gravimetric water content (GWC), available P ( $\mu$ g-P $\bullet \mathrm{g}_{-}{ }^{1}$ oven dry equivalent (ode) soil, (Murphy and Riley 1962; Lajtha et al. 1999) and available $\mathrm{N}$ (dissolved inorganic $\mathrm{N}$ (DIN) in the form of ammonium ( $\mu \mathrm{g}-\mathrm{N}-\mathrm{NH} 4^{+} \mathrm{g}^{-1}$ ode soil) (Sims, 1995; Mulvaney, 1996)). We only analyzed soils collected in the dry season for GWC and available nutrients because we were not able to collect all soils in both seasons and prioritized the dry season. All colorimetric analyses were performed in the Cardelús lab at Colgate University on a BioTEK Powerwave (Winooski, VT).

Disturbance

Disturbance was determined as described in (Cardelús et al. 2019). In brief, three transects were established from the center of the forest to the exterior in three compass directions. All trees and disturbance types (e.g. weedy taxa, native and exotic tree plantations, clearings/gathering areas, buildings, graves) were measured across the transect. Percent disturbance was then calculated across each forest; disturbance across 44 forests averaged 56.2\% ( \pm 3.2) (Cardelús et al. 2019). 
Statistical analyses

The study was designed at three scales: within forests, among forests, and across land cover types (forest, edgeexterior, Eucalyptus plantation). All sta tistical analyses were done using the statistical package $\mathrm{R}$ (R Core Team 2018) and R Studio (RStudio Team 2015).

Within forests

To determine the effects of forest edge on within forest soil nutrients and properties, we ran general linear models with distance from edge and site as the explanatory variables. This allowed us to examine the effect of distance from edge after controlling for the effect of site. When distance from edge was a significant factor in the GLM, we used linear regression analysis to determine if there were linear relationships between distance to edge and soil nutrients and properties.

\section{Among forests}

We used general linear models to statistically evaluate the effects of forest size, disturbance, the presence of a wall, distance to population center, elevation, and size by disturbance interaction on the status of soil nutrients and properties among sacred forests. General linear models were used because it enabled us to conduct several independent univariate tests of each factor on our response variables.

\section{Across land cover type}

To evaluate the effects across land cover type (forest, edge-exterior, Eucalyptus plantation) and elevation (montane or upper montane) on soil physical properties, nutrients, and carbon we used 2-way analysis of Variance (ANOVA) with post-hoc TukeyHSD tests. When we found a significant interaction between land cover type and elevation, a 1-way ANOVA was run to examine the influence of land cover type alone for each elevation, and a 2-sample t-test was run to examine the influence of elevation alone for all land-cover types. Data were log-transformed, when appropriate, to conform with assumptions of normality and homogeneity of variance.

\section{Results}

We collected and processed soils from 23 montane and 17 upper montane church forests, 15 of which had Eucalyptus plantations (Table 1).

Within forests: edge effects

\section{Montane forests}

In the montane region, total $\mathrm{C}$ and $\mathrm{N}$ varied significantly with distance from edge and site (Table 2), increasing linearly with increasing distance from the outer edge of the forest (Fig. 3). Similarly, N:P and C:N ratios and bulk density varied significantly with distance and site; however, they did not vary linearly with increasing distance from edge $\left(\mathrm{N}: \mathrm{P}: \mathrm{R}^{2}=0.02, p=0.121 ; \mathrm{C}: \mathrm{N}\right.$ : $\mathrm{R}^{2}=-0.02, p=0.968$ ); bulk density $=\mathrm{R}^{2}=-0.02, p=$ $0.711)$. $\mathrm{P}$ varied significantly with site but not distance from edge (Table 2).

Available $P$ varied significantly in the dry season with increasing distance from the forest edge and among sites, increasing significantly with distance from edge (Table 3). Ammonium only varied with site and was not significantly influenced by distance from edge (Table 3). Gravimetric water content varied significantly with distance from edge and site, increasing significantly with distance from edge $\left(\mathrm{R}^{2}=0.10, p<0.001\right)$.

\section{Upper montane}

In upper montane forests, $\mathrm{P}, \mathrm{N}: \mathrm{P}$ ratios and bulk density varied significantly with both distance from edge and among sites (Table 2) with N:P ratios and bulk density varying linearly with distance to edge $\left(\mathrm{N}: \mathrm{P}: \mathrm{R}^{2}=0.09\right.$, $p=0.016$; bulk density $=\mathrm{R}^{2}=0.06, p=0.049$ ). All other parameters varied significantly with site but not distance from edge (Table 2).

Unlike in montane forest soils, during the dry season upper montane forest available $\mathrm{P}$ did not vary significantly with either distance from edge or among sites (Table 3). Ammonium varied significantly with site, but not distance from edge within the dry season (Table 3). Gravimetric water content varied significantly with site during the dry season, but not distance from edge. 
Table 2 Two-way ANOVA results examining the effects of distance from edge and site on soil carbon, nutrients, ratios and bulk density within 40 sacred church forests in northern Ethiopia

\begin{tabular}{|c|c|c|c|c|c|c|c|c|}
\hline \multirow[t]{3}{*}{ Soil Nutrient, Ratio or Property } & & \multicolumn{7}{|c|}{ Edge Effects } \\
\hline & & \multicolumn{3}{|c|}{ Montane } & & \multicolumn{3}{|c|}{ Upper Montane } \\
\hline & & Model & $\begin{array}{l}\text { Distance } \\
\text { from Edge }\end{array}$ & Site & & Model & $\begin{array}{l}\text { Distance } \\
\text { from Edge }\end{array}$ & Site \\
\hline \multirow[t]{3}{*}{ Carbon } & $\mathrm{df}$ & 22,41 & 1 & 21 & df & 18,33 & 1 & 21 \\
\hline & $\mathrm{F}$ & 3.00 & 18.63 & 2.25 & $\mathrm{~F}$ & 6.06 & 3.73 & 6.19 \\
\hline & $\mathrm{p}$ & 0.001 & $<0.001$ & 0.013 & $\mathrm{p}$ & $<0.001$ & 0.062 & $<0.001$ \\
\hline \multirow[t]{3}{*}{ Nitrogen } & $\mathrm{df}$ & 22,41 & 1 & 21 & df & 18,33 & 1 & 17 \\
\hline & $\mathrm{F}$ & 2.72 & 15.71 & 2.10 & $\mathrm{~F}$ & 5.02 & 4.51 & 5.05 \\
\hline & $\mathrm{p}$ & 0.003 & $<0.001$ & 0.021 & $\mathrm{p}$ & $<0.001$ & 0.041 & $<0.001$ \\
\hline \multirow[t]{3}{*}{ Phosphorus } & df & 22 & 1 & 21 & $\mathrm{df}$ & 18 & 1 & 17 \\
\hline & $\mathrm{F}$ & 5.55 & 0.14 & 5.8 & $\mathrm{~F}$ & 5.22 & 4.55 & 5.52 \\
\hline & $\mathrm{p}$ & $<0.001$ & 0.714 & $<0.001$ & $\mathrm{p}$ & $<0.001$ & 0.040 & $<0.001$ \\
\hline \multirow[t]{3}{*}{$\mathrm{N}: \mathrm{P}$ ratio } & $\mathrm{df}$ & 22,41 & 1 & 21 & $\mathrm{df}$ & 18,33 & 1 & 17 \\
\hline & $\mathrm{F}$ & 8.89 & 10.22 & 8.83 & $\mathrm{~F}$ & 4.62 & 10.54 & 4.28 \\
\hline & $\mathrm{p}$ & $<0.001$ & 0.003 & $<0.001$ & $\mathrm{p}$ & $<0.001$ & 0.003 & $<0.001$ \\
\hline \multirow[t]{3}{*}{$\mathrm{C}: \mathrm{N}$ ratio } & $\mathrm{df}$ & 22,41 & 1 & 21 & df & 18 & 1 & 17 \\
\hline & $\mathrm{F}$ & 2.52 & 15.71 & 2.10 & $\mathrm{~F}$ & 2.71 & 1.82 & 2.76 \\
\hline & $\mathrm{p}$ & 0.005 & $<0.001$ & 0.021 & $\mathrm{p}$ & 0.006 & 0.186 & 0.006 \\
\hline \multirow[t]{3}{*}{ Bulk Density(g cm-3) } & $\mathrm{df}$ & 20,37 & 1 & 21 & $\mathrm{df}$ & 17,32 & 1 & 16 \\
\hline & $\mathrm{F}$ & 6.00 & 15.71 & 2.10 & $\mathrm{~F}$ & 9329 & 14.13 & 8.99 \\
\hline & $\mathrm{p}$ & $<0.001$ & $<0.001$ & 0.021 & $\mathrm{p}$ & $<0.001$ & $<0.001$ & $<0.001$ \\
\hline
\end{tabular}

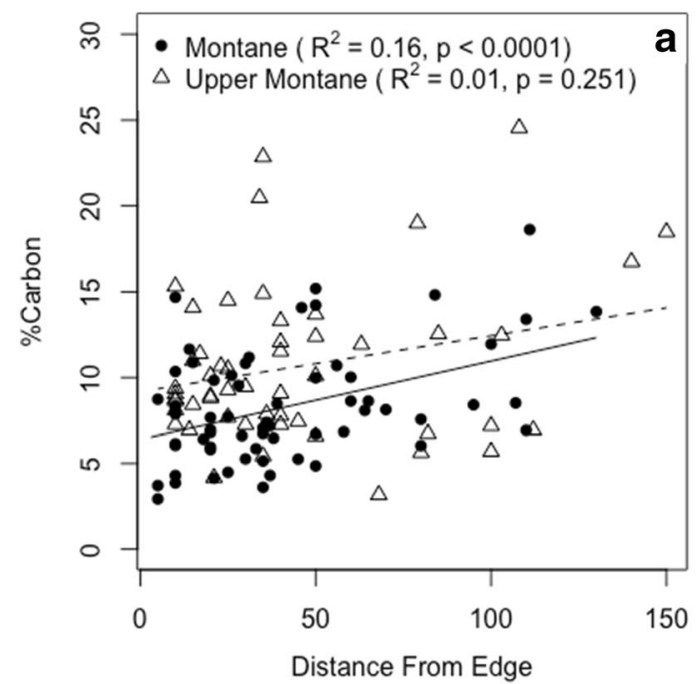

Fig. 3 Linear regression of distance from edge on (a) percent carbon, (b) percent nitrogen, and (c) bulk density $\left(\mathrm{g} / \mathrm{cm}^{3}\right)$ in montane (solid line) and upper montane (dotted line) sacred

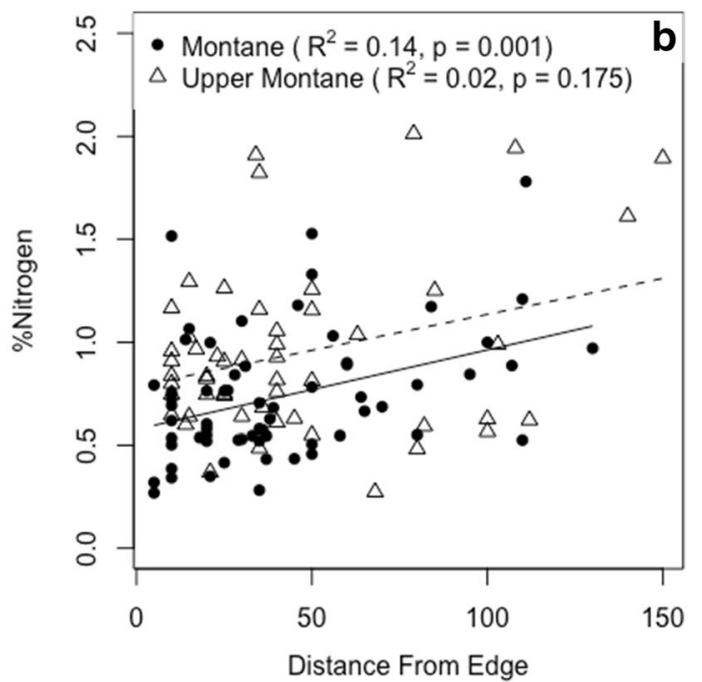

church forests in northern Ethiopia. Analyses performed on logtransformed data but presented without log 
Table 3 General linear model results of the effect of distance from edge and site on dry season available nutrients (ammonium and orthophosphorus) and gravimetric water content (GWC) by elevation (montane, upper montane)

\begin{tabular}{|c|c|c|c|c|c|c|c|}
\hline & & \multicolumn{3}{|c|}{ Montane } & \multicolumn{3}{|c|}{ Upper Montane } \\
\hline & & \multicolumn{3}{|l|}{ Dry } & \multicolumn{3}{|l|}{ Dry } \\
\hline & & Model & Distance from Edge & Site & Model & Distance from Edge & Site \\
\hline \multirow[t]{3}{*}{ Ammonium } & df & 2,35 & 1 & 1 & 2,11 & 1 & 1 \\
\hline & $\mathrm{F}$ & 19.45 & 1.89 & 37.02 & 6.60 & 3.27 & 9.92 \\
\hline & $p$ & $<0.001$ & 0.178 & $<0.001$ & 0.013 & 0.097 & 0.009 \\
\hline \multirow[t]{3}{*}{ Available Phosphorus } & $\mathrm{df}$ & 2,32 & 1 & 1 & 2,11 & 1 & 1 \\
\hline & $\mathrm{F}$ & 33.61 & 11.09 & 56.13 & -0.14 & 0.00 & 0.35 \\
\hline & $p$ & $<0.001$ & 0.002 & $<0.001$ & 0.840 & 0.966 & 0.564 \\
\hline \multirow[t]{3}{*}{ GWC } & df & 2,37 & 1 & 1 & 2,11 & 1 & 1 \\
\hline & $\mathrm{F}$ & 7.42 & 5.53 & 9.31 & 4.04 & 1.85 & 6.23 \\
\hline & $p$ & 0.002 & 0.024 & 0.004 & 0.048 & 0.201 & 0.030 \\
\hline
\end{tabular}

Across forests

We used a general linear model to examine the effects of sacred forest size, elevation, disturbance, distance to population center, the presence of a wall, and a size by disturbance interaction on soil nutrients, ratios, and properties across forests. Forest size, elevation and distance to population center were the only factors that significantly influenced any soil health metrics (Table 4). Percent $\mathrm{C}$ and N:P ratios increased significantly with increasing forest size (Fig. 4). Percent $\mathrm{C}$ and $\mathrm{N}$ were significantly higher, and bulk density significantly lower in forests $<50 \mathrm{~km}$ from a population center
(Fig. 5). Bulk density was also significantly influenced by forest size and elevation, decreasing with increasing forest size in upper montane forests (Fig. 4). The presence of a wall and the \% disturbance in the forests had no signficant effect on any soil parameters (Table 4).

\section{Land cover type}

All measured soil parameters varied significantly with landcover type (Supplemental 1; Fig. 6). Percent $\mathrm{C}, \mathrm{N}, \mathrm{P}$ and $\mathrm{N}: \mathrm{P}$ ratios were significantly higher and bulk density significantly lower in soils from within the forest compared to soils from the

Table 4 Analysis of variation results on the effects of forests size, percent disturbance, elevation, distance to population center, the presence of a wall and a size $\mathrm{x}$ disturbance interaction on soil

carbon, nutrients, ratios, and bulk density ( $\mathrm{g} \mathrm{cm}-3$ ) across 40 sacred forest in northern Ethiopia

\begin{tabular}{|c|c|c|c|c|c|c|c|c|c|c|c|c|}
\hline & \multicolumn{3}{|c|}{ Carbon } & \multicolumn{3}{|c|}{ Nitrogen } & \multicolumn{3}{|c|}{ N:P Ratio } & \multicolumn{3}{|c|}{ Bulk Density } \\
\hline & $\mathrm{df}$ & $\mathrm{F}$ & $p$ & $\mathrm{df}$ & $\mathrm{F}$ & $p$ & $\mathrm{df}$ & $\mathrm{F}$ & $p$ & df & $\mathrm{F}$ & $p$ \\
\hline Model & 6,33 & 2.65 .9 & 0.033 & 6,33 & 2.48 & 0.043 & 6,33 & 2.47 & 0.044 & 6,33 & 4.66 & 0.002 \\
\hline Forest Size & 1 & 5.36 & 0.027 & 1 & 3.89 & 0.571 & 1 & 7.91 & 0.008 & 1 & 5.73 & 0.022 \\
\hline$\%$ Disturbance & 1 & 0.97 & 0.332 & 1 & 0.86 & 0.361 & 1 & 0.18 & 0.677 & 1 & 1.79 & 0.190 \\
\hline Elevation & 1 & 2.48 & 0.125 & 1 & 2.49 & 0.124 & 1 & 0.62 & 0.438 & 1 & 8.58 & 0.006 \\
\hline Distance to Population Center & 1 & 5.73 & 0.023 & 1 & 6.06 & 0.019 & 1 & 3.33 & 0.077 & 1 & 10.95 & 0.002 \\
\hline Presence of a wall & 1 & 0.17 & 0.681 & 1 & 0.45 & 0.507 & 1 & 0.22 & 0.145 & 1 & 0.890 & 0.352 \\
\hline \multirow[t]{3}{*}{ Size x Disturbance } & 1 & 1.22 & 0.278 & 1 & 1.14 & 0.295 & 1 & 0.57 & 0.456 & 1 & 0.025 & 0.876 \\
\hline & \multicolumn{3}{|c|}{ Phosphorus } & \multicolumn{3}{|c|}{$\mathrm{C}: \mathrm{N}$ ratio } & & & & & & \\
\hline & df & $\mathrm{F}$ & $p$ & $\mathrm{df}$ & $\mathrm{F}$ & $p$ & & & & & & \\
\hline Model & 6,33 & 1.44 & 0.231 & 6,33 & 0.49 & 0.808 & & & & & & \\
\hline
\end{tabular}


Fig. 4 Linear regression between church forest size and (a) percent Carbon, (b) nitrogen:phosphorus ratios and (c) bulk density (across church forests in montane (solid line) and upper montane (dotted line) forests
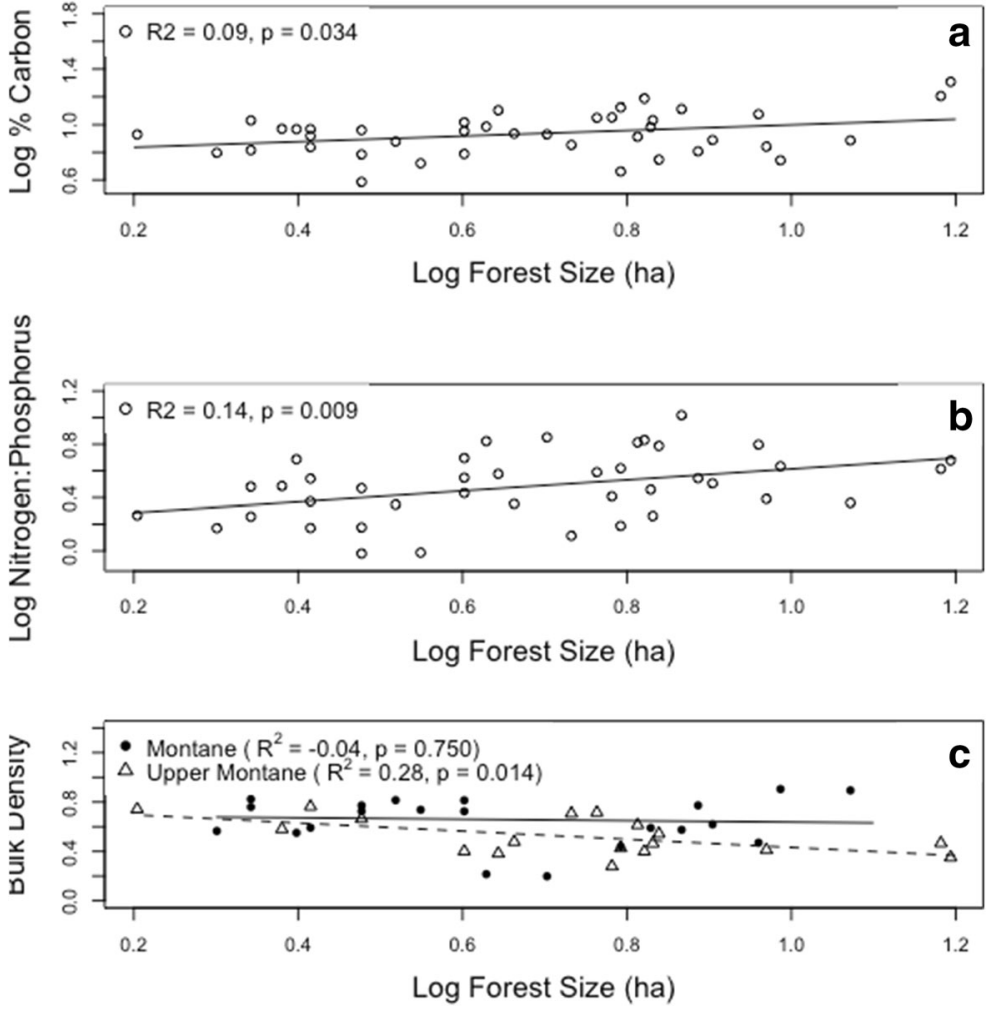

edge-exterior. Forest soils also varied with Eucalyptus plantation soils, with forest soils having significantly higher $\mathrm{C}$ and $\mathrm{N}$ but similar $\mathrm{P}, \mathrm{C}: \mathrm{N}$ and $\mathrm{N}: \mathrm{P}$ ratios, and bulk densities (Fig. 6).

\section{Discussion}

Our research on the soil nutrient chemical and physical properties of 40 Ethiopian sacred church forests indicates

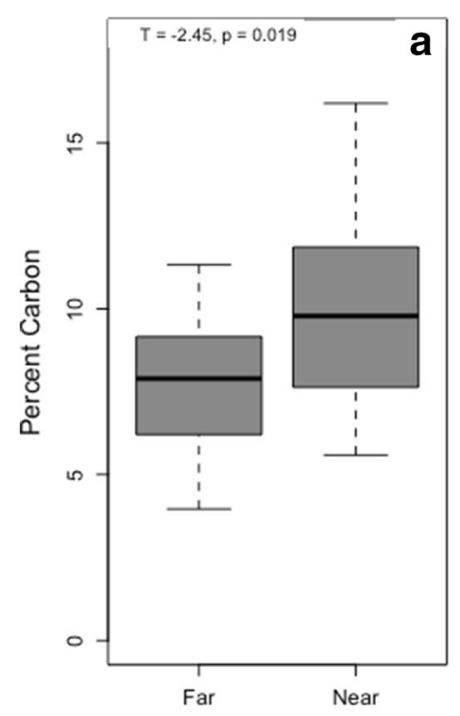

Distance to Population Center

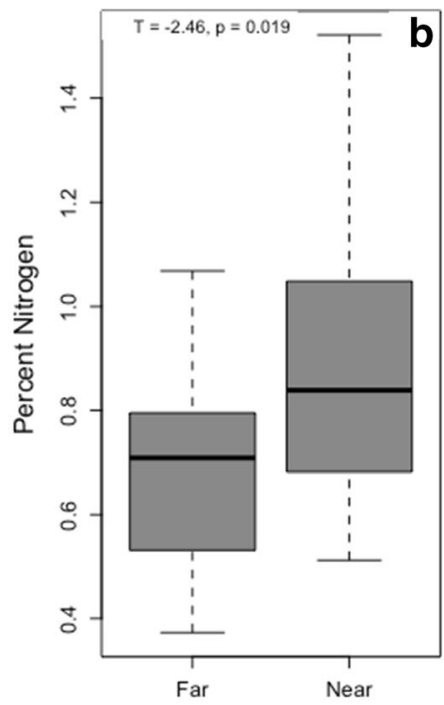

Distance to Population Center

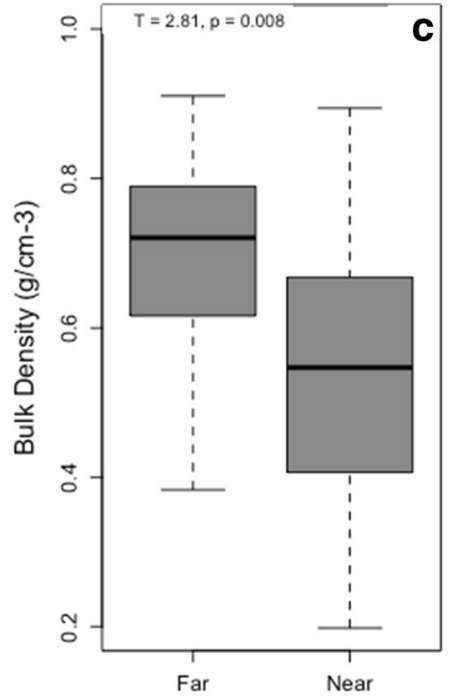

Distance to Population Center

Fig. 5 Box and whiskers plots of (a) percent carbon, (b) percent nitrogen and (c) bulk density with distance to population center. Student's ttest performed on logged data when appropriate and presented non-logged 


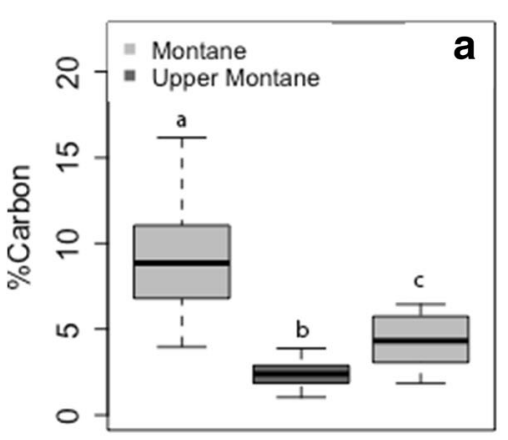

Forest Exterior Eucalyptus

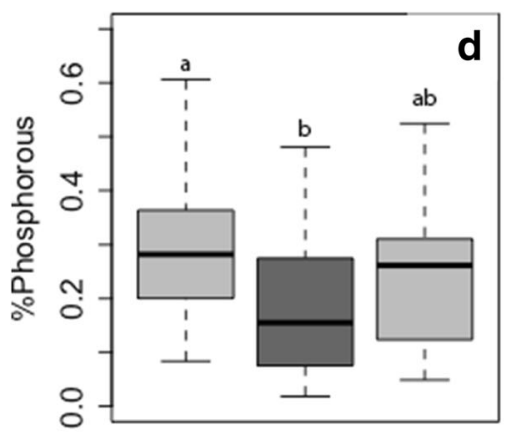

Forest Exterior Eucalyptus

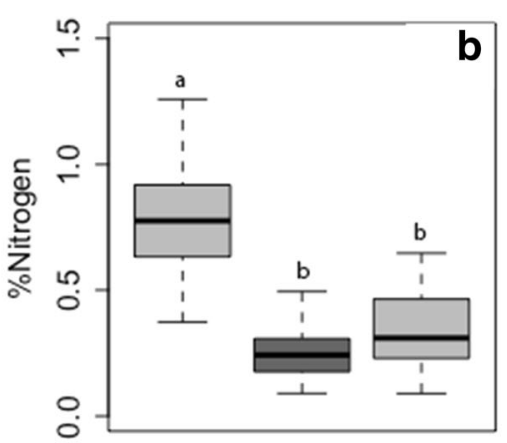

Forest Exterior Eucalyptus

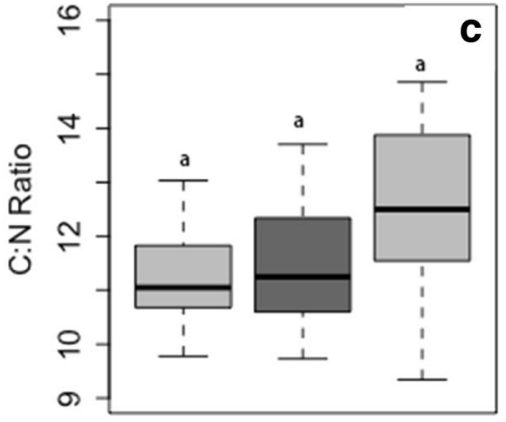

Forest Exterior Eucalyptus

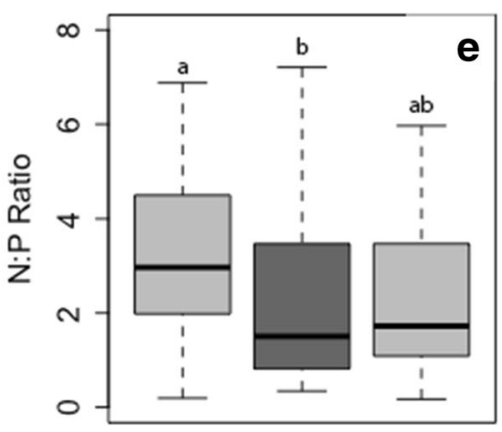

Forest Exterior Eucalyptus

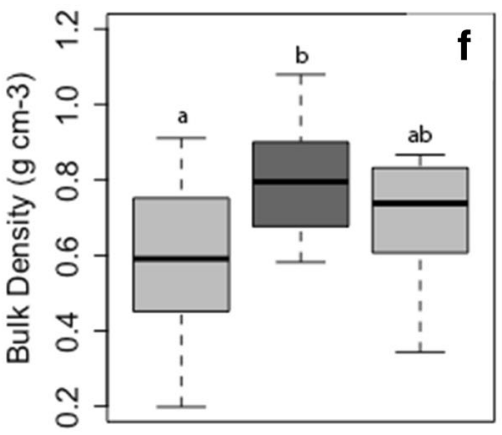

Forest Exterior Eucalyptus
Fig. 6 Box and whiskers plots of soil parameters measured across land-use types and elevation: (a) \%Carbon, (b) \% Nitrogen, (c) $\mathrm{C}: \mathrm{N}$ ratio, (d) \% Phosphorus, (e) N:P ratio, and (f) bulk density.

that larger forests have greater soil nutrient status and $\mathrm{C}$ concentrations than smaller forests. All forests, regardless of size, have greater soil nutrient status compared to forest edge-exterior and nearby Eucalyptus plantation soils.

Within forests: edge effects

In this study, we found that within forest soil nutrients and physical properties were negatively influenced by proximity to edge, particularly in the montane region. The montane and upper montane sites were different in what nutrients and properties varied. Overall, in montane forests C, $\mathrm{N}$, available $\mathrm{P}$, and GWC increased with distance from the edge (Fig. 3). Whereas, in the upper montane forests $\mathrm{P}$, $\mathrm{N}: \mathrm{P}$ ratios, available $\mathrm{P}$ and $\mathrm{NH}_{4}$ increased with distance from edge. These results are consistent with data from the region (Cardelús et al. 2013; Liang et al. 2016) and previous research on the negative effects of edges on forest
Different lowercase letters indicate significant differences among land-use types. Analyses performed on log-transformed data but presented without log

nutrients, with greater concentrations of total and available nutrients, and $\mathrm{C}$ in larger forests (Magnago et al. 2015).

The variation in soil chemistry between elevations may reflect floristic and structural differences (Wassie et al. 2010). Montane forests are dominated by tall canopy trees with a closed canopy, whereas the upper montane forests have a lower tree density and more open habitat than montane forests (Cardelús et al. 2017). Upper montane forests are characterized by high abundance of the charismatic Euphorbia, cactus-like trees, that have a small and open canopy, which could affect nutrient cycling by abiotic transformations or microbial activity through increased light or temperature within forests. The consistently open canopy of upper montane forests likely reduces variation from the edge to interior, homogenizing the forest from the interior to the edge. Whereas, the variation in microclimate from the edge to interior of montane forests is more pronounced. 
GWC increases with distance from the edge, corresponding with increased available $\mathrm{P}$ and $\mathrm{NH}_{4}$ in montane forests but not in upper montane forests. This indicates that water availability mediates nutrient availability in lower elevation systems and that interior forest, and hence larger forest, is critical to soil and plant health. In contrast, bulk density is more important in upper montane forests, suggesting that decreasing human and animal traffic is more important at high elevations. Higher GWC allows for greater forest productivity, as plants can photosynthesize longer before the wilting point (Archer and Smith 1972; Tolk 2003); higher soil mineralization rates and thus available nutrients (Stanford and Epstein 1974); and higher likelihood of seed germination and establishment (Holl 1999). Forest fragmentation (i.e. edge effects) has significant negative effects on seedling recruitment, germination, and establishment linked to greater microclimatic stresses such as increased temperature and reduced humidity (Bruna 1999, 2002; Laurance et al. 2002, 2018). These edge effects cannot be avoided given that most edge effects are felt $50 \mathrm{~m}$ into the forest and the majority of forests in the region are $<16$ ha and the mean distance to edge in this study was $43.6 \mathrm{~m}( \pm 3.03)$. However, as seen by the variation in bulk density with forest size (Fig. 4), edge effects can be buffered even in small forests.

Sacred church forests exhibited greater variation among sites than within sites in soil nutrients, C, and physical properties (Tables 2 and 3). The consistently significant effect of site on soil parameters highlights the individuality of these sacred forests. The significant variation among sites may seem surprising as individual forests within an elevation share macroclimate and soil type as they are spatially close to each other $(2.10 \mathrm{~km} \pm$ 0.03) (Cardelús et al. 2013), however; they are part of separate human communities and under different local leadership as each forest has a resident head priest who runs the daily operations (Klepeis et al. 2016). The effects of social dynamics and forest use (e.g. leadership, attendance, community engagement, socioeconomic status, perceived holiness, etc.) may be influencing within forest ecological processes. Fragmentation also impacts forest composition over time through extinction debt, while small forests are also more prone to stochastic effects that could eliminate species from the fragment, leading to a differences in soil characteristics across sites and potentially forest composition (Krauss et al. 2010; Laurance et al. 2018).

\section{Across forests}

Percent $\mathrm{C}, \mathrm{N}, \mathrm{N}: \mathrm{P}$ ratios and bulk density varied across forests for multiple potential drivers of soil variation (Table 4). Not surprisingly, smaller forests have lower $\mathrm{C}$ than larger forests and had higher bulk densities (Fig. 5). Smaller forests have a higher edge/forest ratio amplifying edge effects such as higher temperature and lower humidity which can, over time, reduce the composition of trees from old growth canopy trees to pioneers species with lower wood density (Laurance et al. 2011). Smaller forests are also vulnerable to greater soil compaction from human and animal use which increases bulk density and can limit seedling growth (Murty et al. 2002; Wassie et al. 2009a).

Forests closer to a population center had significantly higher C, N (Fig. 4) and lower bulk density than forest $>50 \mathrm{~km}$ from a population center (Fig. 5). These data are initially counterintuitive because forest degradation is historically higher near population centers (Geist and Lambin 2002) which would result in lower $C$ and higher bulk density (more compact soil). A possible explanation is higher dependence of the rural population on these forests for natural resources (e.g. fuelwood, shade, etc.) compared to urban centers, leading to greater impacts on forest soils. While Cardelús et al. (2019) found no significant effect of distance from population center on forest disturbance in these sites, the number of people and their forest use is still unclear.

Walls are not a common occurrence across these forests (Klepeis et al. 2016) but they are advocated as a conservation strategy in this region to decrease access to pastured animals and to funnel visitors to particular paths (Wassie et al. 2009b; Woods et al. 2017). However, the presence of a wall had no significant effect on any soil parameters which is surprising given the potential for walls to act as wind-breaks between agricultural land and forests, which could act to increase soil moisture and decrease erosion.

Disturbance did not have a significant effect on soil physical and chemical properties. This result was surprising given that within these same forests disturbance has significant and negative effects on tree density, richness, and biomass and seedling richness and density (Cardelús et al. 2019). The lack of a significant effect of disturbance on soil physical and chemical properties highlights the potential differential effects of disturbance on forest processes and indicates that variation in forest size and population density has a stronger effect 
on soil processes than disturbance (Cardelús et al. 2019). A more detailed analysis of the type of disturbance, with further analyses of micronutrients, enzymatic activities, $P$ fractions, and microbial community could shed more light into the subtle effects of disturbance on these forests.

\section{Land cover type}

Our data clearly show that Eucalyptus plantations are not comparable to native forests in soil physical and chemical properties as forest soils had higher nutrient and carbon content than both the edge-exterior of the forest or Eucalyptus plantations (Fig. 6). In fact, Eucalyptus plantation soil chemistry was more similar to the forest edge-exterior than the native forest, with similar results found across Ethiopian regions (Liang et al. 2016). These results are not surprising as Eucalyptus is a problematic species ecologically. Eucalyptus leaves have strong allelopathic effects on non-Eucalyptus germination rates (del Moral and Muller 1970); in fact, we found no seedlings in any Eucalyptus plantation that we studied (pers. Obs). Eucalyptus trees prevent more soil losses from erosion than open fields but do not facilitate the same nutrient returns as native forests because organic material is removed through harvesting and does not replenish the soil (Bargali et al. 1993; Jagger and Pender 2003). In addition, Eucalyptus depletes water from the soil as it has significantly higher evapotranspiration rates than local taxa (Fetene and Beck 2004; Fritzsche et al. 2006). The increased planting of Eucalyptus for income generation over the last 50 years is a major concern to the welfare of these forests (Scull et al. 2017).

For example, these sacred church forest soils hold $\sim 50 \%$ more $\mathrm{C}(8.7 \% \pm 6.1)$ than both the edge-exterior $(4.1 \% \pm 0.8)$ and Eucalyptus plantations $(4.2 \% \pm 0.4)$ and $>60 \%$ more $\mathrm{N}(1.50 \% \pm 0.3)$ than both the edgeexterior $(0.58 \pm 0.15)$ and Eucalyptus plantations ( 0.34 $\pm 0.04)$. These $\mathrm{C}$ losses between forest soil and the edgeexterior have occurred over at least the last 50 years and highlights the importance of forests to the maintenance of $\mathrm{C}$ stocks in forest fragments.

\section{Conclusion}

The impact of edge effects and human disturbance on soil physical properties shed light on the soil nutrient status of these forest. Edge effects result in lower GWC which limits biological and physical processes of nutrient cycling within the soil. Increased bulk density, due to human and animal presence in these forests, decreases pore spaces for water and air critical to supporting these nutrient cycling mechanisms. These two soil physical properties exert a significant control over nutrient availability to plants and microbes, likely contributing to the decrease in aboveground biomass documented in Cardelús et al. (2019). This dynamic sets up a feedback where edge effects degrade both plant and soil health in a continuous cycle unless effective conservation strategies can be implemented.

Our research on the soil status of church forests in northern Ethiopia shows that forest soils are negatively impacted by human disturbance and edge effects. Forest size had the greatest influence on soil physical and chemical properties. This study aligns with research across forests examining the negative impacts of disturbance and small size on forest species richness, abundance, biomass, forest regeneration, and canopy openness (Scull et al. 2017; Cardelús et al. 2019). Unfortunately, the threat to these forest and their soils is not unique, as recent work by Haddad et al. (2015) has found that $20 \%$ of the world's forests are within $100 \mathrm{~m}$ of an edge. These forest fragments may be the only refugia for regional biodiversity (Wassie 2007; Arroyo-Rodríguez et al. 2009; Aerts et al. 2016; Cardelús et al. 2017), and critical for ecosystem processes such as decomposition and nutrient and carbon cycling. An added element to the need for their conservation is their importance culturally. Ethiopian church forests may be small in size but provide significant economic and social benefits to the community, as well as ecosystem services. Conservation strategies should include limiting foot traffic, planting native taxa within the forest, and protecting seedlings from trampling by people and animals. We recommend that the Ethiopian Environmental Protection Authority, Ministry of Agriculture and other concerned bodies address the increasing disturbance in these forests and the need for their protection.

Acknowledgements We acknowledge the students of the Cardelús and Scull labs at Colgate University, the Woods lab at the University of Puget Sound, and the Tsegay lab at the University of Bahir Dar, Ethiopia, for their contributions to the lab and field work. We are also grateful to the respected Ethiopian priests and monks for allowing us access to their sacred church forests. This work was funded through the Dynamics of Coupled Natural Human Ecosystems Program of the National Science Foundation 
[Award No. 1518501]. Initial work was funded by The Picker Interdisciplinary Science Institute at Colgate University: http://www.colgate.edu/centers-and-institutes/pickerinterdisciplinary-science-institute. Acquisition of the mass spectrometer at Colgate University was supported by NSF [EAR-0216179].

Open Access This article is licensed under a Creative Commons Attribution 4.0 International License, which permits use, sharing, adaptation, distribution and reproduction in any medium or format, as long as you give appropriate credit to the original author(s) and the source, provide a link to the Creative Commons licence, and indicate if changes were made. The images or other third party material in this article are included in the article's Creative Commons licence, unless indicated otherwise in a credit line to the material. If material is not included in the article's Creative Commons licence and your intended use is not permitted by statutory regulation or exceeds the permitted use, you will need to obtain permission directly from the copyright holder. To view a copy of this licence, visit http://creativecommons.org/licenses/by/4.0/.

\section{References}

Aerts R, Van Overtveld K, November E et al (2016) Conservation of the Ethiopian church forests: threats, opportunities and implications for their management. Sci Total Environ 551: 404-414

Archer J, Smith P (1972) The relation between bulk density, available water capacity, and air capacity of soils. J Soil Sci 23:475-480

Arroyo-Rodríguez V, Pineda E, Escobar F, Benítez-Malvido J (2009) Value of small patches in the conservation of plantspecies diversity in highly fragmented rainforest. Conserv Biol 23:729-739

Bargali S, Singh R, Joshi M (1993) Changes in soil characteristics in eucalypt plantations replacing natural broad-leaved forests. J Veg Sci 4:25-28

Blake GR, Hartge KH (1986) Bulk denstity. In: Klute A (ed) Methods of soil analysis, part 1 . Physical and mineralogical methods, agronomy monograph no. 9, 2nd edn. American Society of Agronomy, Inc. \& Soil Science Society of America, Inc., Madison, pp 363-382

Boerma P (2006) Assessing forest cover change in Eritrea-a historical perspective. Mt Res Dev 26:41-48

Bruna EM (1999) Biodiversity: seed germination in rainforest fragments. Nature 6758:139

Bruna EM (2002) Effects of forest fragmentation on Heliconia acuminata seedling recruitment in Central Amazonia. Oecologia 132:235-243

Cardelús CL, Scull P, Hair J, Baimas-George M, Lowman M, Eshete A (2013) A preliminary assessment of Ethiopian sacred groves at the landscape and ecosystem scales. Diversity 5:320-334
Cardelús CL, Scull P, Wassie A et al (2017) Shadow conservation and the persistence of sacred forests in northern Ethiopia. Biotropica 49:725-733

Cardelús CL, Woods CL, Mekonnen AB et al (2019) Disturbance impacts the integrity of sacred church forests, Ethiopia. PlosONE 14:e0212430

del Moral R, Muller CH (1970) The allelopathic effects of Eucalyptus camaldulensis. Am Midl Nat 83:254-282

Delgado JA, Gantzer CJ (2015) The 4Rs for cover crops and other advances in cover crop management for environmental quality. J Soil Water Conserv 70:142A-145A

Dudley N, Higgins-Zogib L, Mansourian S (2009) The links between protected areas, faiths, and sacred natural sites. Conserv Biol 23:568-577

Echeverna C, Coomes D, Salas J et al (2006) Rapid deforestation and fragmentation of Chilean temperate forests. Biol Conserv 130:481-494

Fetene M, Beck EH (2004) Water relations of indigenous versus exotic tree species, growing at the same site in a tropical montane forest in southern Ethiopia. Trees 18:428-435

Fritzsche F, Abate A, Fetene M, Beck E, Weise S, Guggenberger G (2006) Soil-plant hydrology of indigenous and exotic trees in an Ethiopian montane forest. Tree Physiol 26:1043-1054

Geist HJ, Lambin EF (2002) Proximate causes and underlying driving forces of tropical deforestation. Bioscience 52:143150

Guo L, Gifford R (2002) Soil carbon stocks and land use change: a meta analysis. Glob Change Biol 8:345-360

Haddad NM, Brudvig LA, Clobert J et al (2015) Habitat fragmentation and its lasting impact on Earth's ecosystems. Sci Adv 1:e1500052

Holl KD (1999) Factors limiting tropical rain forest regeneration in abandoned pasture: seed rain, seed germination, microclimate, and soil 1. Biotropica 31:229-242

Huth T, Porder S, Chaves J, Whiteside JH (2012) Soil carbon and nutrient changes associated with deforestation for pasture in southern Costa Rica. Biotropica 44:661-667

Jagger P, Pender J (2003) The role of trees for sustainable management of less-favored lands: the case of eucalyptus in Ethiopia. For Policy Econ 5:83-95

Jones JB, Case BW (1996) Soil testing and plant analysis no. 3. In: Sparks DL (ed) Methods of soil analysis part 3: chemical methods. Soil Science Society of America, Madison, pp 389 415

Klepeis P, Orlowska I, Kent E et al (2016) Ethiopian church forests: a hybrid model of protection. Hum Ecol 44:715-730

Krauss J, Bommarco R, Guardiola M, Heikkinen RK, Helm A, Kuussaari M, Lindborg R, Öckinger E, Pärtel M, Pino J, Pöyry J, Raatikainen KM, Sang A, Stefanescu C, Teder T, Zobel M, Steffan-Dewenter I (2010) Habitat fragmentation causes immediate and time-delayed biodiversity loss at different trophic levels. Ecol Lett 13:597-605. https://doi. org/10.1111/j.1461-0248.2010.01457.x

Lajtha K, Driscoll CT, Jarrell WM, Elliott ET (1999) Soil phosphorus: characterization and total element analysis. In: Robertson GP, Coleman DC, Bledsoe CS, Sollins P (eds) Standard soil methods for long-term ecological research. Oxford University Press, New York, pp 115-142

Laurance W, Laurance S, Ferreira L et al (1997) Biomass collapse in Amazonian forest fragments. Science 278:1117-1118 
Laurance W, Lovejoy T, Vasconcelos H et al (2002) Ecosystem decay of Amazonian forest fragments: a 22 year investigation. Conserv Biol 16:605-618

Laurance WF, Camargo JLC, Luizão RCC, Laurance SG, Pimm SL, Bruna EM, Stouffer PC, Bruce Williamson G, BenítezMalvido J, Vasconcelos HL, van Houtan KS, Zartman CE, Boyle SA, Didham RK, Andrade A, Lovejoy TE (2011) The fate of Amazonian forest fragments: a 32-year investigation. Biol Conserv 144:56-67

Laurance WF, Useche DC, Rendeiro J et al (2012) Averting biodiversity collapse in tropical forest protected areas. Nature 489:290-294

Laurance WF, Camargo JL, Fearnside PM et al (2018) An Amazonian rainforest and its fragments as a laboratory of global change. Biol Rev 93:223-247

Liang J, Reynolds T, Wassie A et al (2016) Effects of exotic Eucalyptus spp. plantations on soil properties in and around sacred natural sites in the northern Ethiopian highlands. Agric Food 1:175-193

Magnago LFS, Magrach A, Laurance WF, Martins SV, MeiraNeto JAA, Simonelli M, Edwards DP (2015) Would protecting tropical forest fragments provide carbon and biodiversity cobenefits under REDD+? Glob Change Biol 21: $3455-3468$

McCann JC (1997) The plow and the forest: narratives of deforestation in Ethiopia, 1840-1992. Environ Hist 2:138-159

Mulvaney RL (1996) Nitrogen-inorganic forms. In: Bartels JM (ed) Methods of soil analysis. Part 3. Chemical Methods. Soil Science Society of America and American Society of Agronomy, Madison, WI

Murphy J, Riley HP (1962) A modified single solution method for the determination of phosphate in natural waters. Anal Chim Acta 27:31-36

Murty D, Kirschbaum MUF, Mcmurtrie RE, Mcgilvray H (2002) Does conversion of forest to agricultural land change soil carbon and nitrogen? A review of the literature. Glob Change Biol 8:105-123

Nigussie Z, Tsunekawa A, Haregeweyn N, Adgo E, Nohmi M, Tsubo M, Aklog D, Meshesha DT, Abele S (2017) Farmers' perception about soil erosion in Ethiopia. Land Degrad Dev 28:401-411

R Core Team (2018) A language and environment for statistical computing. R Foundation for Statistical Computing, Vienna, Austria

Riutta T, Slade EM, Bebber DP, Taylor ME, Malhi Y, Riordan P, Macdonald DW, Morecroft MD (2012) Experimental evidence for the interacting effects of forest edge, moisture and soil macrofauna on leaf litter decomposition. Soil Biol Biochem 49:124-131. https://doi.org/10.1016/j. soilbio.2012.02.028

RStudio Team (2015) RStudio: integrated development for R. RStudio, Inc., Boston, MA URL http://www.rstudio.com/

Scull P, Cardelús CL, Klepeis P, Woods CL, Frankl A, Nyssen J (2017) The resilience of Ethiopian church forests: interpreting aerial photographs, 1938-2015. Land Degrad Dev 28:450-458. https://doi.org/10.1002/ldr.2633

SGAZDA (2004) South Gondar Zonal Department of Agriculture: Annual Report. Gondar, ET.

Sims GK TR Ellsworth \& RL Mulvaney (1995) Microscale determination of inorganic nitrogen in water and soil extracts. Community and Soil Science Plant Annals 26:303-316

Stanford G, Epstein E (1974) Nitrogen mineralization-water relations in soils 1. Soil Sci Soc Am J 38:103-107

Tolk JA (2003) Soils, permanent wilting points. Encycl Water Sci 120010337:92

Villalobos S, Vamosi JC (2016) Increasing land use drives changes in plant phylogenetic diversity and prevalence of specialists. PeerJ 4:e1740

Wassie A (2002) Opportunies, constraints, and prospects of the Ethiopian orthodox Tewahido churches in conserving Forest resources: the case of churches in south Gonder, Northern Ethiopia. Swedish University of Agricultural Sciences

Wassie A (2007) Ethiopian church forests: opportunities and challenges for restoration. Wageningen University

Wassie A, Sterck F, Teketay D, Bongers F (2009a) Tree regeneration in church forests of Ethiopia: effects of microsites and management. Biotropica 41:110-119

Wassie A, Sterck FJ, Teketay D, Bongers F (2009b) Effects of livestock exclusion on tree regeneration in church forests of Ethiopia. For Ecol Manag 257:765-772

Wassie A, Sterck FJ, Bongers F (2010) Species and structural diversity of church forests in a fragmented Ethiopian Highland landscape. J Veg Sci 21:938-948

Woods CL, Cardelús CL, Scull PR, Wassie A, Baez M, Klepeis P (2017) Stone walls and sacred forest conservation in Ethiopia. Biodivers Conserv 26:209-221

Publisher's note Springer Nature remains neutral with regard to jurisdictional claims in published maps and institutional affiliations. 